\title{
The Synthesis of DL-3,3-Difluoroglutamic Acid from a 3-Oxoprolinol Derivative
}

\author{
Barry P. Hart and James K. Coward* \\ Department of Chemistry \\ and \\ Interdepartmental Program in Medicinal Chemistry, College of Pharmacy, \\ University of Michigan, Ann Arbor, MI 48109-1055
}

\begin{abstract}
DL-3,3-Difluoroglutamic acid was synthesized from a masked 3-hydroxyprolinol, 6-hydroxy-1-aza-3oxabicyclo[3.3.0]octan-2-one, in eight steps. The described synthetic route expands the utility of fluoroproline derivatives as precursors of fluoroglutamic acids.
\end{abstract}

Prior research in this laboratory has identified the fluoroglutamic acids as useful modulators of folate poly$\gamma$-glutamate biosynthesis. ${ }^{1}$ Specifically, L-threo-4-fluoroglutamic acid $(2 S, 4 S)$ has been shown to act as a chain-terminating inhibitor of the enzyme folylpolyglutamate synthetase (FPGS, EC 6.3.2.17). ${ }^{2}$ The L-erythro $(2 S, 4 R)$ diastereomer is much less effective. Similarly, the erythro and threo diastereomers of 4-fluoroglutamic acid, when incorporated into folic acid and the anticancer drug, methotrexate, have proven to be useful probes of the role of polyglutamate biosynthesis in both folic acid-mediated one-carbon biosynthesis ${ }^{1}$ and methotrexate cytotoxicity. ${ }^{3}$ In contrast, we have shown recently that DL-3,3-difluoroglutamic acid acts as an enhancer of polyglutamate chain elongation. 4 Thus, we have the ability either to inhibit or stimulate the biosynthesis of the polyanionic, polyglutamate "conjugates" of intracellular folates (and pharmacologically useful folic acid derivatives such as leucovorin) or anticancer drugs such as methotrexate. ${ }^{5}$

Previous syntheses of 4-fluoroglutamic acid isomers or 3,3,-difluoroglutamic acid involved the use of diethylfluoromalonate or 2,2-difluoro-4-pentenenitrile, respectively. 3,4 Unfortunately, the supply of these precursors is quite limited and the overall yield of the final fluoroglutamic acid product, especially in the case of the 3,3-difluoro derivative, is extremely low. Therefore, we have initiated a synthetic program to provide an ample supply of several fluoroglutamates for further biochemical and pharmacological studies. The general approach is outlined in Scheme 1 and involves the use of proline derivatives as glutamate precursors. 6

Scheme 1<smiles>[R]C([R2])([R2])C([R2])([R2])[C@@H](N)C(=O)O</smiles>
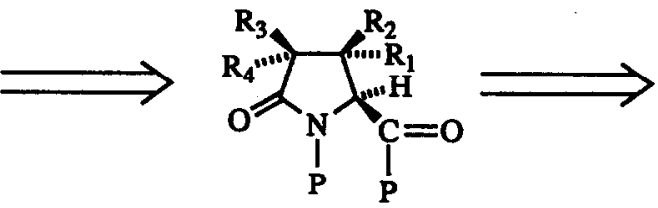

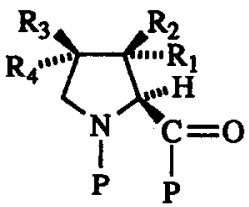

a) $\mathbf{R}_{1}=\mathbf{R}_{\mathbf{2}}=\mathbf{R}_{\mathbf{3}}=\mathrm{H} ; \mathbf{R}_{\mathbf{4}}=\mathrm{F}$ (L-erythro FGlu)

b) $\mathbf{R}_{\mathbf{1}}=\mathbf{R}_{\mathbf{2}}=\mathbf{R}_{4}=\mathbf{H} ; \mathbf{R}_{\mathbf{3}}=\mathbf{F}$ (L-threo FGlu)

c) $\mathbf{R}_{1}=\mathbf{R}_{\mathbf{2}}=\mathbf{F} ; \mathbf{R}_{\mathbf{3}}=\mathbf{R}_{\mathbf{4}}=\mathbf{H}\left(\mathrm{L}-\mathrm{F}_{\mathbf{2}} \mathrm{Glu}\right)$

In the present research, we have taken this approach to synthesize DL-3,3-difluoroglutamic acid. Based on our previous experience with (diethylamino)sulfur trifluoride, (DAST), in the synthesis of 4-

fluoroglutamate, ${ }^{6}$ we planned to use this reagent to convert a 3-oxoproline to the corresponding 3,3-difluoro 
derivative. However, the requisite 3-ketoproline esters have been studied extensively by Rapoport et al., and have been shown to be prone to facile rearrangement. ${ }^{7}$ Therefore we chose a masked 3-hydroxyprolinol (2),8 with both the secondary amino and hydroxymethyl groups incorporated in a cyclic carbamate, as the starting material (Scheme 2). In this communication, the synthesis of 1 from 6-hydroxy-1-aza-3-oxabicyclo[3.3.0] octan-2-one (2) is reported.

\section{Scheme $2^{\text {n }}$}<smiles>CC(C)C1CC2C(=O)N1CCC2O</smiles>

2<smiles>O=C1CCN2C(=O)OCC12</smiles>

3 (b)<smiles>C1CCC2(CC1)CC21CCCCC1</smiles><smiles>CC(C)(C)C1C2OC(=O)N3CCC(F)(F)C1C23</smiles>

4<smiles>O=C1CC(F)(F)C2COC(=O)N12</smiles>

5

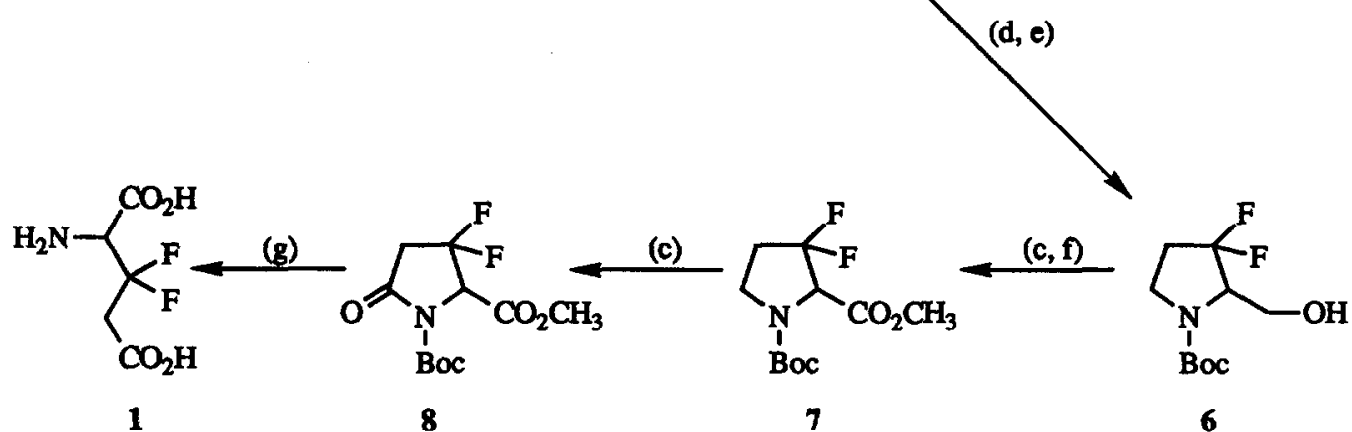

aReagents: (a) ( $\left.\mathrm{CF}_{3} \mathrm{C}(\mathrm{O})\right)_{2} \mathrm{O}$; DMSO; $\mathrm{Et}_{3} \mathrm{~N} ; \mathrm{CH}_{2} \mathrm{Cl}_{2}$ (73\%); (b) DAST, $\mathrm{CH}_{2} \mathrm{Cl}_{2},-78{ }^{\circ} \mathrm{C} \rightarrow \mathrm{RT}$ (64\%);

(c) $\mathrm{RuO}_{2} \cdot \mathrm{xH}_{2} \mathrm{O}, 10 \% \mathrm{NaIO}_{4}, \mathrm{EtOAc}$; (d) $6 \mathrm{~N} \mathrm{HCl}, \triangle$; (e) (Boc) $2 \mathrm{O}, \mathrm{NaHCO}_{3} \mathrm{CHCl}_{3}, \mathrm{H}_{2} \mathrm{O}$ (92\% from 4);

(f) $\mathrm{CH}_{2} \mathrm{~N}_{2}, \mathrm{Et}_{2} \mathrm{O}$ (93\% from 6); (g) Conc. $\mathrm{HCl}, \Delta(7 \rightarrow 1,40 \%)$.

Oxidation of compound 2 under Swern conditions ${ }^{9}$ afforded the ketone $3\left(\mathrm{mp} 98-99^{\circ} \mathrm{C}\right)$ in $73 \%$ yield; attempts to oxidize 2 with $\mathrm{RuO}_{4}$ resulted in low yields of 3. Treatment of 3 with DAST provided compound 4 in $64 \%$ yield as a yellow oil. ${ }^{10,11}$ Attempts to oxidize 4 to the desired bicyclic lactam 5 with $\mathrm{RuO}_{4}$ yielded only recovered starting material after 5 days at ambient temperature.

Literature precedent is available for the oxidation of proline ${ }^{12}$ and 4-fluoroproline ${ }^{6}$ derivatives to the desired lactams in high yield. However, with a fluoromethylene group adjacent to the desired site of oxidation, the latter compound is oxidized much more slowly than the non-fluorinated proline derivative. The presence of an adjacent difluoromethylene moiety completely prevents $\mathrm{RuO}_{4}$ oxidation. ${ }^{13}$ In this research, the difluorooxazolidinone 4 was hydrolyzed to the prolinol derivative and converted to 7 in order to determine if a 3,3-difluoromethylene group would prevent $\mathrm{RuO}_{4}$-mediated oxidation to the difluoro lactam 8 . Compound 4 was hydrolyzed in refluxing $6 \mathrm{~N} \mathrm{HCl}$; the resulting crude difluoro amino alcohol solution was evaporated to dryness and the secondary amine protected as the t-butyl urethane 6 in $92 \%$ yield from 4.14 
Compound 6 was oxidized to the carboxylic acid and the acid esterified with diazomethane to provide 7 in $93 \%$ yield. 15 The oxidation 12 of 7 to the $\beta, \beta$-difluorolactam 8 required $6-12$ days stirring at room temperature. The reaction mixture turned from yellow $\left(\mathrm{RuO}_{4}\right)$ to black $\left(\mathrm{RuO}_{2}\right)$ several times during the 12 days and required five additional aliquots of $10 \%$ aq. $\mathrm{NaIO}_{4}\left(2 \mathrm{~mL} /\right.$ aliquot) to maintain the $\mathrm{RuO}_{4}$ oxidation state. An analytical sample of compound $8^{16}$ was obtained by recrystallization from $\mathrm{E}_{2} \mathrm{O}$ /hexane. Although attempts to purify 8 by column chromatography failed, 17 the material isolated from the reaction mixture was sufficiently pure for use in the next step. Thus, hydrolysis of compound 8 in refluxing $12 \mathrm{~N} \mathrm{HCl}$ provided 1,18 the desired 3,3-difluoroglutamic acid, in $40 \%$ overall yield from 7.

Having successfully achieved our goal of effecting an improved synthesis of DL-3,3-difluoroglutamic acid using a racemic precursor, we should be able to extend this method to the stereospecific synthesis of the $L$ enantiomer using an appropriate chiral precursor (Scheme 1). Such experiments are currently in progress.

Acknowledgements: This research was supported in part by a grant from the National Institutes of Health, CA28097, and a National Research Service Award (T32 GM07767) to B.P.H. We thank Jane MacDonald for careful preparation of the manuscript.

\section{REFERENCES AND FOOTNOTES'}

1. Coward, J. K.; McGuire, J. J.; Galivan, J. In Selective Fluorination in Organic and Bioorganic Chemistry; J. T. Welch, Ed.; American Chemical Society: Washington, D.C., 1991; pp 196-204.

2. McGuire, J. J.; Coward, J. K. J. Biol. Chem. 1985, 260, 6747-6754.

3. McGuire, J. J.; Graber, M.; Licato, N.; Vincenz, C.; Coward, J. K.; Nimec, Z.; Galivan, J. Cancer Res. $1989,49,4517-4525$.

4. McGuire, J. J.; Haile, W. H.; Bey, P.; Coward, J. K. J. Biol. Chem. 1990, 265, 14073-14079.

5. Matherly, L. H.; Seither, R. L.; Goldman, I. D. Pharmacol. Ther. 1987, 35, 27-56.

6. Our initial research on this chemistry involved the use of 4-hydroxyproline derivatives as precursors of 4fluoroglutamate stereoisomers. While our studies were in progress, Hudlicky and Merola published a paper which described the successful synthesis of L-threo-4-fluoroglutamic acid from trans-4-hydroxy-Lproline (Hudlicky, M.; Merola, J. S. Tetrahedron Lett. 1990, 31, 7403-7406). We have confirmed the utility of their synthetic method and have used it, with slight modifications, to prepare more substantial quantities of the L-threo diastereomer for use in our biochemical research. We thank Professor Hudlicky for providing details on the synthesis and for an authentic sample of the product.

7. Blake, J.; Willson, C. D.; Rapoport, H. J. Am. Chem. Soc. 1964, 86, 5293-5299.

8. Compound 2 was obtained in five steps from acetonitrile and acrolein as described by Tamaru et al. (Tamaru, Y.; Kawamura, S-I.; Bando, T.; Tanaka, K.; Hojo, M.; Yoshida, Z-C. J. Org. Chem. 1988, $53,5491-5501)$

9. Huang, S. L.; Omura, K.; Swern, D. J. Org. Chem. 1976, 41, 3329-3331.

10. Compound 4 was isolated by adding ice- $\mathrm{CH}_{2} \mathrm{Cl}_{2}$ to the reaction mixture, partitioning the organic-aqueous mixture, and concentrating the dried organic layer in vacuo. The isolated material was pure as judged by $1_{\mathrm{H} N M R}$ and ${ }^{13} \mathrm{C}$ NMR. HRMS calcd for $\mathrm{C}_{6} \mathrm{H}_{7} \mathrm{~F}_{2} \mathrm{NO}_{2} 163.0445$, found 163.0452

$11 \mathrm{l}_{\mathrm{H}}$ and ${ }^{13} \mathrm{C}$ NMR spectral data are referenced to TMS as an internal or external standard in $\mathrm{CDCl}_{3}$ or $\mathrm{D}_{2} \mathrm{O}$, respectively. ${ }^{19} \mathrm{~F}$ NMR spectral data are referenced to $\mathrm{CF}_{3} \mathrm{COOH}$ as an external standard.

12. Yoshifuji, S.; Tanaka, K-I.; Kawai, T.; Nitta, Y. Chem. Pharm. Bull. 1985, 33, 5515-5521.

13. Hart, B. P.; Coward, J. K. Unpublished results with 4,4-difluoroproline derivatives.

14. 6: IR $v_{\max } 3473,1686 \mathrm{~cm}^{-1}$; ${ }^{1} \mathrm{H}$ NMR $\left(300 \mathrm{MHz} \mathrm{CDCl}_{3}\right) \delta 4.0-3.65(\mathrm{~m}, 3 \mathrm{H}), 3.5(\mathrm{t}, 2 \mathrm{H}), 2.4-2.2$ $(\mathrm{m}, 2 \mathrm{H}), 1.45(\mathrm{~s}, 9 \mathrm{H}) .{ }^{13} \mathrm{C} \mathrm{NMR}\left(90 \mathrm{MHz} \mathrm{CDCl}_{3}\right) \delta 155.3,127.3,81.2,64.2(\mathrm{t}), 61.3,43.4,33.2$ (t), 28.5. ${ }^{19}$ F NMR (282 MHz; $\left.\mathrm{CDCl}_{3}\right) \delta-36.8(\mathrm{dd}),-22.4(\mathrm{dm})$ and $-18.0(\mathrm{dm})$. MS (CI) m/e (rel 
intensity) $238(\mathrm{MH}+, 9), 199$ (37), 182 (100), 138 (26). HRMS calcd for $\mathrm{C}_{10} \mathrm{H}_{17} \mathrm{~F}_{2} \mathrm{NO}_{3}$ (MH+)

238.1255, found 238.1249. Anal. Calod for $\mathrm{C}_{10} \mathrm{H}_{17} \mathrm{~F}_{2} \mathrm{NO}_{3} \cdot 0.1 \mathrm{H}_{2} \mathrm{O}: \mathrm{C}, 50.25 ; \mathrm{H}, 7.17 ; \mathrm{N}, 5.86$.

Found C, 49.91; H, 7.31; N, 5.56.

15. 7: ${ }^{1} \mathrm{H}$ NMR (300 MHz; $\left.\mathrm{CDCl}_{3}\right) \delta 4.5(\mathrm{~m}, 2 \mathrm{H}, \alpha \mathrm{CH}), 3.70-3.50\left(\mathrm{~m}, 5 \mathrm{H} \delta \mathrm{CH}_{2}\right.$ and $\left.\mathrm{CH}_{3}\right) 2.50-2.35$ $\left(\mathrm{m}, 2 \mathrm{H}, \mathrm{CCH}_{2}\right), 1.5\left(\mathrm{~d}, 9 \mathrm{H}, \mathrm{C}\left(\mathrm{CH}_{3}\right)\right) ;{ }^{13} \mathrm{C} \mathrm{NMR}\left(90 \mathrm{MHz} \mathrm{CDCl}_{3}\right) 8167.8,153.0,126.1 \mathrm{~m}$ ), 81.0, 64.7 (m), 52.7 (d), 43.0 (d), 32.9 (m), 28.1; 19F NMR (282 MHz; CDCl 3 ) $\delta$-31.0 (m), -18.7 (m); MS (Cl) m/e (rel intensity); $283\left(\mathrm{M}+\mathrm{NH}_{4}+, 7\right), 266(\mathrm{MH}+, 4), 227$ (100), 166 (28), 136 (79); HRMS calcd for $\mathrm{C}_{11} \mathrm{H}_{17} \mathrm{~F}_{2} \mathrm{NO}_{4}(\mathrm{MH}+)$ 266.1204, found 266.1198.

16. 8: $\left.{ }^{1} \mathrm{H} \mathrm{NMR} \mathrm{(300} \mathrm{MHz;} \mathrm{CDCl}_{3}\right) \delta 4.90-4.80(\mathrm{~d}, 1 \mathrm{H}, \alpha \mathrm{CH}), 3.88\left(\mathrm{~s}, 3 \mathrm{H}, \mathrm{CH}_{3}\right), 3.29-2.98(\mathrm{~m}, 2 \mathrm{H}$, $\mathrm{\gamma CH}_{2}$ ), 1.45 (s, $\left.9 \mathrm{H}, \mathrm{C}\left(\mathrm{CH}_{3}\right)_{3}\right) ;{ }^{13} \mathrm{C} \mathrm{NMR}\left(90 \mathrm{MHz} \mathrm{CDCl}_{3}\right) \delta 165.6$ (dd), 148.0, 118.8 (d), 85.2, 66.4, 53.4, 41.3 (t), 27.8; ${ }^{19} \mathrm{~F}$ NMR $\delta\left(282 \mathrm{MHz}\right.$; $\left.\mathrm{CDCl}_{3}\right) \delta-31.6$ (dd), $-13.6(\mathrm{dm}) ; \mathrm{MS}(\mathrm{Cl}) \mathrm{m} / \mathrm{e}$ (rel intensity) $297\left(\mathrm{M}+\mathrm{NH}_{4}, 36\right), 280(\mathrm{MH}+, 2), 197$ (49), 177 (42), 136 (100); HRMS calcd for $\mathrm{C}_{11} \mathrm{H}_{15} \mathrm{~F}_{2} \mathrm{NO}_{5}\left(\mathrm{M}+\mathrm{NH}_{4}\right)$ 297.1262, found 297.1259. Anal. Calcd for $\mathrm{C}_{11} \mathrm{H}_{15} \mathrm{~F}_{2} \mathrm{NO}$ : $\mathrm{C}, 47.31 ; \mathrm{H}$, $5.41 ; \mathrm{N}, 5.02$. Found: $\mathrm{C}, 47.33 ; \mathrm{H}, 5.23 ; \mathrm{N}, 4.90$.

17. Attempted purification of 8 by chromatography (solid phase-neutral alumina, silica gel, silica gel treated with $\mathrm{Et}_{3} \mathrm{~N}$ or $(\mathrm{Me} 3 \mathrm{Si})_{2} \mathrm{NH}$; mobile phase $-66 \%$ hexane in EtOAc) resulted in the elimination of $\mathrm{HF}$.

18. 1: ${ }^{1} \mathrm{H}$ NMR (300 MHz; $\left.\mathrm{D}_{2} \mathrm{O}\right) \delta 4.65-4.51$ (dd, $\left.1 \mathrm{H}, \alpha \mathrm{CH}\right), 3.60-3.36\left(\mathrm{~m}, 2 \mathrm{H}, \gamma_{\mathrm{CH}_{2}}\right) ;{ }^{13} \mathrm{C} \mathrm{NMR}(360$ $\left.\mathrm{MHz}_{2} \mathrm{D}_{2} \mathrm{O}\right) \delta 170.7$ (d), 167.2 (d), $119.2(\mathrm{t}), 57.5$ (q), 39.9 (t). ${ }^{19} \mathrm{~F}$ NMR $\delta\left(282 \mathrm{MHz} ; \mathrm{CDCl}_{3}\right) \delta-22.1$ $(\mathrm{dm}),-27.5(\mathrm{dm}) .{ }^{19} \mathrm{~F}$ and ${ }^{1} \mathrm{H}$ NMR properties of 1 agree with authentic sample from Marion MerrellDow. 4 